\title{
Restrukturisasi kognitif untuk mengurangi gejala kecemasan pada wanita yang mengalami premenopause
}

\author{
Debby Afradipta ${ }^{1}$
}

\begin{abstract}
The subject is an 45 years old women who has been divorced since 2013. She has a problem in the form of negative thoughts that lead to symptoms of anxiety and always appear in his life. The assessment methods used were observation, interview, psychological test (WAIS, Graphic, SSCT, and Beck Anxiety Scale). The intervention given is Cognitive Therapy using Cognitive Restructuring techniques. The goal is to reduce the symptoms of anxiety experienced by the subject. After giving the intervention for 6 sessions, she was able to change her views and perceptions with more positive thoughts.
\end{abstract}

\section{Keywords}

Cognitif restructurisation, anxiaty

\section{Pendahuluan}

Menopause merupakan proses alami yang dialami setiap wanita. Namun pada sebagian wanita, masa menopause merupakan saat yang paling menyedihkan dalam hidup. Ada banyak kekhawatiran yang menyelubungi pikiran wanita ketika memasuki fase ini. Penelitian The Indonesian Journal of Public Health, menunjukkan bahwa 75\% wanita yang mengalami menopause merupakan suatu masalah atau gangguan, sedangkan $25 \%$ lainnya tidak mempermasalahkannya (Kasdu, 2007).

Banyak ibu-ibu yang mengalami menopause menjadi seorang yang mudah mengalami cemas. Kecemasan ini timbul sebagai akibat seringnya kekhawatiran yang menghantui dalam menghadapi situasi yang sebelumnya tidak pernah mereka khawatirkan. Wanita yang memiliki pengetahuan baik maka akan lebih mampu mengatasi kecemasannya, sedangkan yang memiliki pengetahuan kurang cenderung mengalami kecemasan berat. Kecemasan bukan hanya sakit secara emosioanal tapi karena ada kesalahan dalam pengetahuan, semakin banyak pengetahuan yang diketahuinya maka kecemasan akan lebih mudah untuk diatasi (Kasdu, 2007).

Kecemasan atau anxietas adalah rasa khawatir, takut yang tidak jelas sebabnya. Pengaruh kecemasan terhadap tercapainya kedewasaan, merupakan masalah penting dalam perkembangan kepribadian. Menurut ?, kecemasan adalah perasaan takut yang tidak jelas dan tidak didukung oleh situasi. Ketika merasa cemas, seseorang merasa tidak nyaman atau takut atau mungkin memiliki firasat akan ditimpa malapetaka padahal ia tidak mengerti mengapa emosi yang mengancam tersebut terjadi.

Kecemasan merupakan masalah psikologis yang dialami oleh individu sehingga diperlukan penanganan dengan menggunakan pendekatan-pendekatan psikologis. Merujuk American Psychological Association (2010) pendekatan kognitif perilaku dan pendekatan behavioral merupakan pendekatan yang efektif untuk menangani masalah gangguan kecemasan. American Psychological Association (2010) menyatakan pendekatan kognitif perilaku sangat efektif dalam mengobati gangguan kecemasan. Para terapis menggunakan pendekatan kognitif perilaku untuk membantu individu yang mengalami kecemasan agar dapat mengidentifikasi dan belajar untuk mengelola faktor- faktor yang berkontribusi terhadap kecemasan yang dialaminya. Sedangkan pendekatan behavioral untuk menangani masalah gangguan kecemasan bertujuan untuk mengurangi atau menghentikan perilaku-perilaku yang tidak diinginkan terkait dengan gangguan kecemasan.

Dobson \& Dobson (2009) mengemukakan tiga klasifikasi pokok dari terapi kognitif perilaku yang memiliki perbedaan fokus tujuan terapi yaitu restrukturisasi kognitif, terapi keterampilan coping, dan terapi pemecahan masalah. Terapi dengan teknik restrukturisasi kognitif memiliki asumsi perilaku yang maladaptif merupakan konsekuensi dari pikiran yang salah. Terapi keterampilan coping menekankan pada keterampilan perkembangan, yakni keterampilan yang dibentuk untuk membimbing Subjek melakukan coping.

Teori restrukturisasi kognitif menyatakan kepercayaan yang tidak realistis secara langsung bertanggung jawab untuk menghasilkan disfungsional emosi dan perilaku, seperti stres, depresi, kecemasan, dan penarikan sosial, dan manusia dapat menghilangkan emosi dan pengaruhnya dengan membongkar keyakinan yang memberi kehidupan. Melalui teknik restrukturisasi kognitif, permasalahan kecemasan

\footnotetext{
${ }^{1}$ Klinik Psikologi Badan POM, Jakarta
}

\section{Korespondensi:}

Debby Afradipta. Klinik psikologi Badan POM, Jl. Percetakan Negara No.23 Jakarta Pusat

Email: afradiptadebby@gmail.com 
ditangani melalui pengubahan pikiran menjadi pikiranpikiran yang positif sehingga adanya pandangan yang netral dan tidak menimbulkan perilaku yang bermasalah.

Permasalahan yang dialami Subjek, merujuk pada permasalahan-permasalahan mengenai kognitif Subjek. Teori kognitif meyakini bahwa individu yang mengadopsi cara berpikir yang negatif memang memiliki resiko yang lebih besar untuk mengalami kecemasan dan gejala depresi bila dihadapkan pada pengalaman hidup yang menekan atau mengecewakan (Nevid et al., 2005). Dalam kasus ini, terapis mengajarkan pada Subjek untuk menggunakan pernyataanpernyataan yang lebih positif dan adaptif dalam menanggapi atau menginterpretasikan kondisi yang dialaminya. Subjek juga diajak untuk melihat pikiran - pikiran yang keliru mengenai kondisi yang ia alami, apakah pikirannya tersebut benar - benar masuk akal atau justru membuat keadaan Subjek semakin tidak baik.

\section{Metode Asesmen}

Metode asesmen yang digunakan adalah Wawancara, Observasi dan Tes Psikologi. Wawancara dilakukan terhadap Subjek serta significant others dari Subjek untuk memperoleh informasi yang lebih mendalam terkait dengan riwayat permasalahan yang Subjek alami (data autoanamnesa dan alloanamnesa). Wawancara dilakukan kepada Subjek, anak Subjek, dan sahabat Subjek. Sedangkan observasi dilakukan untuk memperoleh informasi terkait dengan perilaku dan aktivitas Subjek serta keadaan lingkungan sekitar selama Subjek berada dilingkungan tempat tinggal Subjek.

Metode tes proyektif diberikan pada Subjek dalam upaya menemukan pola perilaku dan pola pemikiran yang mencerminkan fungsi kepribadian Subjek yang belum terungkapkan. Adapun tes proyektif yang digunakan yaitu tes grafis yang terdiri dari 3 macam yaitu, Draw A Person (DAP), BAUM dan House Tree Person (HTP). Pemberian tes grafis bertujuan untuk menganalisis kepribadian yang komprehensif dari kepribadian mulai dari dinamikanya hingga sindrom-sindrom klinis yang terproyeksi dari masing-masing objek gambar. Sedangkan tes non proyektif yang diberikan adalah Sack's Sentence Completion Test (SSCT) yakni untuk melihat penyesuaian diri Subjek dalam aspek keluarga, heteroseksual, hubungan interpersonal dan penyesuaian diri.

Tes Weschler Adult Inteligence Scale (WAIS) juga diberikan untuk mengetahui taraf keberfungsian inteligensi Subjek, skor IQ dan kemunduran mental Subjek. Tes WAIS ini diberikan sebagai data penunjang untuk mengetahui apakah intervensi dengan teknik restrukturisasi kognitif bisa diterapkan sesuai kondisi Subjek. Selain itu diberikan Instrumen Pengukuran Diri (Self-report) yaitu Beck Anxiety Inventory (BAI). Skala ini diberikan untuk mengukur tingkat kecemasan Subjek dengan tiga tingkatan yakni kecemasan berat (skor $i$ 36), kecemasan sedang (skor 22 - 35) dan kecemasan ringan (skor $0-21$ ).

\section{Presentasi Kasus}

Subjek adalah seorang perempuan dewasa berusia 45 tahun. Saat ini Subjek tidak bekerja dan menjadi ibu rumah tangga. Subjek merupakan anak ke lima dari enam bersaudara.
Ibu Subjek sudah meninggal sejak Subjek memiliki satu anak dan ayah Subjek merupakan pensiunan PNS. Subjek memiliki dua orang anak laki-laki. Anak pertama Subjek sedang mengenyam pendidikan di salah satu perguruan tinggi di kota $\mathrm{S}$ sedangkan anak kedua Subjek saat ini duduk dikelas VII SMP. Subjek hanya tinggal bersama anak keduanya dirumah. Subjek sudah bercerai dengan suaminya pada tahun 2013 yang lalu.

Subjek datang ke puskesmas dengan keluhan mengalami premenopause dengan gejala fisik seperti semburan panas (hot flushes), vertigo dan keringat banyak, migraine. Gejala psikologis yang dialami oleh Subjek adalah susah tidur (insomnia), kurang konsentrasi, sulit mengambil keputusan dan konflik keluarga. Gejala ini sudah berlangsung selama 5 bulan sejak Oktober 2016. Subjek merasa bahwa sejak ia sakit, tidak ada orang yang memperhatikannya. Ibu Subjek sudah meninggal sedangkan ayah Subjek bersikap tidak peduli dengan keadaan Subjek. Semua saudara Subjek juga tidak memperdulikannya.

Subjek termasuk dalam komunitas pecinta alam jawa timur yang sering mengadakan kegiatan untuk naik gunung sedari ia masih gadis. Subjek juga tak jarang mendampingi temannya untuk menjadi pemandu naik gunung. Dikarenakan aktivitas Subjek yang seperti itulah, saudara Subjek beranggapan bahwa Subjek selalu sibuk jalan-jalan terus dan wajar saja jika Subjek jatuh sakit. Sehingga saudara tidak ada yang memperdulikan Subjek. Menurut cerita Subjek ketika ia berpergian dengan teman laki- lakinya untuk naik gunung, saudara Subjek berpikir hal yang negatif terhadap dirinya. Keluarganya berpikir bahwa lelaki itu adalah pacar Subjek yang mengajak Subjek untuk cek in di hotel. Informasi tersebut diperoleh Subjek dari tetangga yang ia percayai dan ayahnya sendiri. Hal ini turut menjadi beban pikiran bagi Subjek.

Rasa sakit yang Subjek alami sejak 5 bulan yang lalu dan tak kunjung sembuh membuat Subjek sudah berusaha berobat kemana pun. Mulai dari terapi medis, pijat refleksi hingga herbal namun tidak membuahkan hasil. Subjek menceritakan bahwa sebelum ia mengalami sakit dengan gejala premenopause dan rasa pusing tersebut, ada sebuah kejadian yang membuat ketakutan Subjek menjadi semakin parah. Subjek menceritakan bahwa tetangganya didepan rumahnya yang merupakan saudara sepupunya, meninggal dunia karena menderita sakit kepala. Pada saat itu Subjek ikut melayat dan juga mengikuti prosesi pemakaman. Subjek mengatakan bahwa pada saat itu dirinya masih sehat dan tidak mengalami ketakutan apapun. Namun selang dua hari setelah itu, Subjek mengalami rasa sakit kepala yang sangat hebat dengan semburan panas hingga membuat dirinya kesulitan untuk tidur. Sejak saat itu ia mengalami beberapa gejala kecemasan seperti ketakutan menderita penyakit kronis, ketakutan akan kematian, sulit tidur dan mengkhawatirkan keadaan dan masa depan anaknya jika ia sudah tidak ada (meninggal dunia).

Subjek menceritakan bahwa dulu ketika ia melihat makam dan suasana tebing yang gelap, ia merasa takut. Hal ini juga membuat Subjek merasa takut untuk ke makam ibunya sendiri dan hingga saat ini Subjek juga belum berani berziarah ke makam ibunya sendiri. Hingga rasa ketakutan akan kematian itu terus muncul. Dikarenakan hal itu, Subjek mengalami ketakutan-ketakuan akan kehidupannya dan 
membuat ia tidak bisa tidur. Bahkan ketika ia memejamkan mata, ia merasa sangat takut. Ketika Subjek mengkonsumsi obat tidur agar bisa tidur, ia pun mengalami ketakutan dan keringat dingin. Subjek takut bahwa ia tidak bisa bangun lagi. Subjek merasa bahwa ia akan segera meninggal karena sakitnya yang tak kunjung sembuh. Subjek juga mengatakan bahwa ia takut akan menderita penyakit kronis. Ia berpikir masa depan anaknya seperti apa jika hal yang ia takutkan itu terjadi, pasalnya ia hanya tinggal berdua bersama anak keduanya sehingga ia takut tidak ada yang akan mengurus dan memperdulikan anaknya.

Pikiran-pikiran Subjek seperti itu menjadi suatu permasalahan yang cukup menggangu keseharian Subjek karena berdampak pada pemikiran yang mengarah kepada sebuah keyakinan. Subjek mengalami permasalahan psikologis ini karena terdapat ketidaktepatan dalam sistem kognisi Subjek. Teori Kognitif Beck menjelaskan jika kognisi didefinisikan sebagai fungsi yang melibatkan inferensi tentang pengalaman seseorang dan tentang terjadinya peristiwa di masa datang dan pengontrolannya (Jones, 2011). Manusia perlu beradaptasi dengan lingkungan yang selalu berubah. Kognisi termasuk proses-proses yang melibatkan mengidentifikasi dan memprediksi berbagai hubungan kompleks di antara berbagai kejadian untuk tujuan adaptasi (Jones, 2011).

Perilaku yang muncul pada Subjek lebih disebabkan karena adanya kerentanan kognitif dan adanya distorsi kognitif pada diri Subjek saat ini. Menurut beck, kerentanan kognitif mengacu pada keringkihan kognitif manusia. Oleh karena skema-skema mereka, masing - masing orang memiliki seperangkat kerentanan dan sensitivitas unik yang mempredisposisikannya untuk mengalami distres psikologi. Skema dan keyakinan orang mempengaruhi caranya memproses data tentang dirinya. Jika dia memperlihatkan masalah psikologis, skema dan keyakinan disfungsionalnya membuatnya membiaskan informasi secara sistematik dengan cara yang tidak membantu (Jones, 2011).

Dalam kasus ini, kerentanan kognitif juga dapat terlihat dari beberapa hasil tes psikologi yang sudah dilakukan. Melihat dari hasil tes psikologi (Grafis), Subjek cenderung introvert, menekan masa lalu dan dikuasi oleh emosi yang tidak seimbang. Ketakutan yang Subjek alami membuat ia merasa tidak aman, depresi dan menutup diri dari lingkungan sekitar. Penolakan Subjek terhadap hubungan sosial membuat dirinya terlihat memiliki konflik dengan hubungan manusiawi. Ketakutan yang Subjek alami juga membuat dirinya merasa tertekan dan tidak mampu melakukan sesuatu hal. . Selain itu Subjek merupakan pribadi yang ragu-ragu dalam mengambil keputusan dan cenderung ruwet dengan pikirannya sendiri dengan emosi yang tidak stabil. Kemudian dari hasil instrumen Beck Anxiety Inventory (BAI) yang diberikan pada Subjek menunjukkan hasil skor 33 yang berada pada kategori kecemasan sedang. Beberapa hasil tes psikologi di atas merupakan pertanda jika Subjek memiliki kerentanan kognitif yang membawanya mengalami distorsi kognitif berupa gejala-gejala gangguan kecemasan. Selain itu, hasil tes intelegensi menggunakan tes Weschler Adult Inteligence Scale (WAIS) menunjukkan skor 105 yang masuk dalam kategori intelegensi rata-rata.

Pengalaman negatif yang dialami Subjek menurut beck merupakan masa dimana seseorang yang memiliki kecenderungan depresi seperti memiliki pemikiran negatif itu cenderung mengembangkan skema negatif. Skema negatif merupakan suatu kecenderungan untuk melihat lingkungan secara negatif melalui kehilangan orang tua, tragedi yang terjadi susul menyusul penolakan sosial oleh teman-teman sebaya, kritik para guru, atau sikap depresi orang tua (Davidson et al., 2002). Skema negatif, bersama dengan penyimpangan kognisi, membentuk apa yang disebut oleh Beck sebagai negative triad: pandangan yang sangat negatif tentang diri sendiri, dunia, dan masa depan. "Dunia" dalam triad depresif dalam Beck merujuk pada penilaian seseorang bahwa ia tidak dapat menghadapi berbagai tuntutan lingkungan (Davidson et al., 2002). Dalam kasus Subjek ini terdapat 2 dari 4 penyimpangan kognitif menurut Beck yang muncul dari Subjek yakni arbitrary inference (kesimpulan yang Subjektif) dan overgeneralisasi.

Dalam distorsi kognitif mengarah kepada keyakinan disfungsional itu melekat pada skema-skema kognitif yang memberikan kontribusi pada distorsi kognitif sistematik, yang lebih mudah diakses dalam pikiran otomatis, yang memberi ciri dan mempertahankan distres psikologis. Salah satu contoh distorsi kognitif menurut teori Beck adalah arbitrary inference (inferensi atau kesimpulan sewenang-wenang). Proses menarik kesimpulan tertentu tanpa bukti pendukung dan kadang-kadang bahkan dengan bukti-bukti yang kontradiktif (Beck \& Weishaar, 2005). Salah satu contoh dari kesimpulan sewenang-wenang yang ditunjukkan oleh Subjek adalah dengan gejala fisik tandatanda premenopause seperti merasa pusing, semburan panas dan vertigo yang ia rasakan maka Subjek memiliki pemikiran negatif bahwa ia menderita sakit kronis yang tak kunjung sembuh dan akan meninggal dunia.

Selain itu, terdapat overgeneralisasi yang sesuai dengan penyimpangan kognitif menurut Teori Beck. Overgeneralisasi adalah suatu kesimpulan yang diambil hanya berdasarkan satu peristiwa tunggal yang mungkin tidak penting yang kemudian individu tersebut mendistorsi pemikiran melalui generalisasi yang berlebihan (Knapp \& Beck, 2008). Dalam kasus ini overgeneralisasi yang Subjek tunjukkan dengan pemikiran negatif ketika seseorang mengalami sakit kepala, maka ia menderita sebuah penyakit kronis dan akan segera meninggal.

Hasil asesmen menunjukkan jika Subjek mengalami permasalahan dengan kognitifnya. Distorsi kognitif Subjek memperlihatkan pikiran-pikiran negatif yang mengarah pada gejala kecemasan. Untuk itu terapis menilai pentingnya penggunaan teknik restrukturisasi kognitif untuk mengurangi gejala kecemasan. Terapi dengan menggunakan teknik restrukturisasi kognitif akan diarahkan pada perbaikan fungsi berpikir, merasa dan bertindak dengan menekankan otak sebagai pusat penganalisa, pengambil keputusan, bertanya, dan bertindak dan memutuskan kembali. Kesalahan berpikir yang biasanya bersifat tidak rasional menimbulkan pernyataan diri individu yang negatif.

\section{Diagnosis dan Prognosis}

\section{Diagnosis}

Berdasarkan uraian kasus, hasil asesmen dan rujukan yang ada di Diagnostic and Statistical Manual of Mental Disorder Fifth Edition (DSM-V) (American Psychological 
Association, 2010), maka dapat ditegakkan diagnosis bahwa Subjek memiliki problem psikologi atau masalah-masalah pemikiran negatif yang mengarah pada problem kecemasan dalam problem related to personal: other personal risk factors V15.89 (Z91.89). Masalah kecemasan yang muncul pada diri Subjek meliputi rasa khawatir dan kegelisahan, pusing, sulit berkonsentrasi, dan gangguan tidur.

\section{Prognosis}

Prognosis pada subjek baik karena subjek mampu mengikuti setiap sesi intervensi dengan baik dan segera dilakukannya penangan. Motivasi dari klien juga dapat membantu proses intervensi.

\section{Intervensi}

Pada kasus ini intervensi yang diberikan pada Subjek yang mengalami problem kecemasan adalah melalui pendekatan kognitif, yaitu dengan menggunakan teknik restrukturisasi kognitif. Terapi dengan menggunakan teknik restrukturisasi kognitif akan diarahkan pada perbaikan fungsi berpikir, merasa dan bertindak dengan menekankan otak sebagai pusat penganalisa, pengambil keputusan, bertanya, dan bertindak dan memutuskan kembali. Kesalahan berpikir yang biasanya bersifat tidak rasional menimbulkan pernyataan diri individu yang negatif.

Teknik restrukturisasi kognitif membantu mengidentifikasi ide-ide atau keyakinan yang irasional dan menggantinya dengan pernyataan-pernyataan yang lebih realistis dan rasional (Suryaningrum, 2007). Metode restrukturisasi kognitif merupakan metode terapi kognitif untuk membantu mengidentifikasikan pemikiran-pemikiran atau keyakinan keyakinan negatif dan menggantikannya pemikiranpemikiran yang positif, serta untuk menolong orang-orang mengidentifikasikan ide-ide atau keyakinan yang irasional tersebut dan menggantinya dengan pernyataan-pernyataan yang lebih realitas (Suryaningrum, 2007). Intervensi pada kasus ini terbagi dalam 6 sesi dengan target intervensi adalah untuk mengurangi gejala kecemasan yang dialami oleh Subjek.

Sesi 1: Membangun rapport. Pada sesi ini Subjek dan terapis saling memperkenalkan diri dan Subjek diminta untuk menceritakan perjalanan hidupnya. Subjek menceritakan kejadian yang dialaminya dan latar belakang kehidupannya dengan cukup detail. Setelah selesai bercerita, Subjek diminta menuliskan keluhan-keluhan yang dirasakannya saat ini. Beberapa keluhan yang ditulis Subjek mengarah kepada problem kecemasan seperti susah tidur, cemas dan khawatir yang berlebih. Problem kecemasan tersebut membawa Subjek menjadi mudah berpikir negatif pada semua hal. Pada akhir sesi 1 ini, Subjek juga menyatakan kesediaannya untuk melanjutkan proses intervensi ini dan disepakatinya untuk pertemuan sesi kedua.

Sesi 2: Identifikasi Permasalahan. Terapis dan Subjek bersama-sama melakukan pengidentifikasian pikiran negatif atau irasional yang menimbulkan kecemasan dan kekhawatiran. Subjek diminta menuliskan pikiran-pikiran negatif yang sering dipikirkan Subjek. Pada sesi ini Subjek juga diminta mengisi skala Beck Anxiety Inventory untuk melihat tingkat kecemasan yang dialami Subjek. Hasil skala ini menunjukkan jika Subjek mengalami gejala kecemasan tingkat sedang. Selain itu Subjek dan terapis sepakat untuk mengurangi pikiran-pikiran negatif itu supaya dapat mereduksi gejala kecemasan Subjek.

Sesi 3: Restrukturisasi kognitif yaitu menjelaskan hubungan antara pikiran - emosi - tingkah laku Terapis menjelaskan pada Subjek hubungan antara pikiran - emosi tingkah laku yang dimiliki oleh Subjek. Subjek diminta untuk merefleksikan apa yang dilakukan selama ini sudah tepat atau belum. Terapis menjelaskan bahwa bagaimana pikiran negatif Subjek, kemudian emosi yang dimunculkan Subjek sehingga muncul perilaku cemas dan khawatir Subjek. Dalam sesi ini Subjek berhasil merefleksi diri dan mempelajari pikiran-pikirannya, emosi dan perilaku yang dia lakukan. Subjek menyadari ada yang keliru dalam proses berpikirnya sehingga yang muncul hanya pikiran negatif dan perilaku yang mengarah pada gejala kecemasan umum.

Sesi 4 \& 5: Restrukturisasi kognitif yaitu mengajarkan pemikiran positif/ rasional Terapis menjelaskan dan mengajarkan pada Subjek alternatif - alternatif pemikiran yang lebih positif atau rasional. Teknik restrukturisasi kognitif yang digunakan meliputi mengidentifikasi situasi yang dirasa Subjek adalah suatu permasalahan (menjelaskan peristiwa atau masalah yang sedang mengganggu Subjek). Kemudian mengidentifikasi distorsi kognitif Subjek, dan perasaan yang dirasakan. Bagaimana perasaan Subjek (sedih, marah, cemas, bersalah, frustrasi, putus asa) mengenai situasi yang menjadi sumber permasalahan. Selanjutnya menggunakan teknik kolom untuk menuliskan pikiran negatif yang berhubungan dengan perasaan serta menuliskan seberapa besar tingkat pemikiran dan perasaan tersebut. Membuat skala dari 0-10 tingkat setiap pemikiran dan perasaan negatif yang diyakini Subjek (untuk tingkatan yang paling rendah hingga tinggi). Setelah itu, mendiskusikan hasil dan mengajari Subjek untuk mencari dan menggantikan pemikiran negatif tersebut dengan pemikiran- pemikiran yang lebih rasional dengan memastikan bahwa pemikiran rasional dapat dan telah diyakini oleh Subjek.

Sesi 6: Evaluasi dan terminasi. Pada sesi ini terapis menunjukkan kepada Subjek betapa jauh lebih baik dirasakan jika berpikiran lebih positif dan realistis. Subjek diajak untuk mempertahankan perubahan yang sudah dilewatinya seperti mempertahankan pemikiran Subjek yang sudah lebih positif dan rasional. Subjek juga mulai melakukan teknik restrukturisasi kognitif sendiri tanpa di dampingi terapis lagi. Setiap sesi (pertemuan) yang sudah dilakukan ini durasi waktunya berlangsung antara 60 sampai 90 menit.

\section{Hasil dan Pembahasan}

\section{Hasil}

Hasil dari pemberian intervensi menggunakan terapi kognitif dengan teknik restrukturisasi kognitif pada Subjek menunjukkan perubahan atau perbaikan yang cukup baik seperti yang diharapkan. Hasil ini dilihat dari perubahan perilaku Subjek yang semakin baik dari hari ke harinya.

Perubahan perilaku Subjek diawali dengan mulai bisa tidur lebih awal dari biasanya. Selain itu Subjek mulai bisa merubah perilaku dan pemikiran negatif yang mengarah 
pada gejala gangguan kecemasan ini. Subjek menemukan insight bahwa kecemasan yang dialami Subjek berawal dari pemikiran negatif yang menyebabkan pada perasaan dan perilaku yang negatif pula. Kini Subjek juga mampu memahami bahwa terdapat hubungan antara pemikiran negatif, perasaan, dan perilaku. Selain itu kini Subjek juga mampu mengidentifikasi pemikiran negatif dan merubahnya menjadi pemikiran yang positif sehingga perilaku yang muncul lebih adaptif juga.

Hasil pemberian post-test menggunakan skala Beck Anxiety Inventory (BAI) juga menunjukkan adanya perubahan. Saat pre-test menunjukkan jika Subjek memiliki skor 33 dengan kecenderungan kecemasan tingkat sedang dan setelah intervensi menggunakan teknik restrukturisasi kognitif kemudian dilakukan pengukuran kembali menggunakan skala Beck Anxiety Inventory menunjukkan adanya penurunan gejala kecemasan menjadi tingkat gejala kecemasan ringan dengan skor 21. Sedangkan pada saat follow up menunjukkan adanya penurunan gejala kecemasan pada tingkat kecemasan ringan dengan skor 17. Pada akhir pemberian intervensi subjek mendapat insight.

Pada saat follow up, Subjek merasa dirinya lebih sehat, lebih fresh dengan banyaknya aktivitas yang ia lakukan diantaranya adalah kembali aktif berolahraga dan berjualan susu kedelai. Subjek memiliki pemikiran yang lebih positif mengenai keadaan dirinya. Subjek berpikiran bahwa lingkungan sosialnya juga banyak yang support dengan kondisi Subjek saat ini. Subjek bisa tidur lebih nyenyak tanpa rasa cemas dan gelisah, menjalani hariharinya dengan memperbanyak aktivitas.

Perubahan yang terjadi pada diri Subjek ini didukung oleh keinginan Subjek yang kuat untuk bisa sembuh dan berubah agar dapat kembali beraktivitas dan menjalani hidu bahagia seperti sedia kala. Intervensi yang diberikan ini belum dapat mencapai hasil yang maksimal mengingat keterbatasan waktu yang dimiliki.

\section{Pembahasan}

Pada kasus ini, permasalahan yang paling nampak yakni munculnya gejala-gejala kecemasan berupa pikiran-pikiran negatif pada Subjek yang mengalami gejala kecemasan akibat tanda fisik premenopause namun dibalik itu Subjek memiliki permasalahan yang berat. Intervensi yang dilakukan untuk menangani permasalahan Subjek menggunakan terapi kognitif dengan teknik restrukturisasi kognitif.

Teknik yang digunakan dalam terapi kognitif perilaku adalah teknik yang digunakan untuk membantu perubahan kognitif dan perilaku. Pada terapi kognitif perilaku terdapat proses modifikasi kognitif yang diartikan sebagai upaya untuk merubah perilaku yang nampak dengan mengubah pikiran-pikiran, interpretasi- interpretasi, asumsi-asumsi, dan cara-cara merespon stimulus yang datang (Dobson \& Dobson, 2009). Modifikasi terhadap perilaku Subjek merupakan fokus akhir setelah terapi berfokus pada modifikasi pikiran Subjek. Dobson \& Dobson (2009) mengungkapkan secara garis besar, teknik terapi kognitif perilaku diklasifikasikan ke dalam tiga bagian dengan fokus terapi yang berbeda-beda yaitu terapi keterampilan coping, restrukturisasi kognitif dan terapi pemecahan masalah.
Fokus utama dari teknik restrukturisasi kognitif yaitu mengidentifikasi dan mengubah keyakinan irasional Subjek dan pernyataan diri atau pikiran-pikiran yang negatif. Sehingga permasalahan-permasalahan yang dapat ditangani dengan teknik restrukturisasi kognitif adalah permasalahan yang berasal dari adanya pikiran-pikiran atau keyakinan yang irasional sehingga memunculkan sikap atau perilaku yang maladaptif (Cormier \& Nurius, 2009). Gottlieb menyatakan restrukturisasi kognitif mampu membuat individu bersikap adaptif terhadap kesulitan yang dihadapinya (Hing, 2013).

Restrukturisasi kognitif merupakan salah satu teknik yang digunakan dalam teori kognitif perilaku yang menitikberatkan pada modifikasi pikiran-pikiran yang salah. Teknik restrukturisasi kognitif merupakan suatu proses di mana terapis membantu Subjek mencari pikiran-pikiran selfdefeating dan mencari alternatif rasional sehingga remaja dapat belajar menghadapi situasi-situasi pembangkit kecemasan (Nevid et al., 2005).

Dalam intervensi ini, terapis mengajarkan pada Subjek yang mengalami gejala gangguan kecemasan untuk menggunakan pernyataan-pernyataan yang lebih positif dan adaptif dalam menanggapi atau menginterpretasikan kondisi yang dialaminya. Subjek juga diajak untuk melihat pikiran-pikirannya yang keliru mengenai kondisi yang ia alami apakah pikirannya tersebut benar benar masuk akal, membantunya, menghiburnya atau membuat keadaan Subjek semakin tidak baik.

Sebelumnya Subjek merasakan permasalahan kecemasan umum pada berbagai situasi yang berkaitan dengan masa depan dirinya, masa depan rumah tangganya dan masa depan anaknya. Hal ini dikarenakan Subjek berpikir negatif terhadap keluarganya yang dipengaruhi oleh suaminya dan terhadap kondisi fisiknya. Subjek sempat berpikir negatif dan kurang yakin apakah dirinya bisa mengatasi masalah kecemasan yang dirasakan dengan kondisi sekarang. Namun setelah diberikan intervensi restrukturisasi kognitif kini Subjek lebih siap dan lebih terampil menghadapi situasi yang membuatnya cemas.

Subjek belajar mengubah pemikiran negatif yang diyakininya menjadi pemikiran positif dengan menggunakan kata-kata atau kalimat positiif dalam kehidupan sehariharinya. Contohnya kalimat "saya wanita lemah" diganti dengan kalimat positif "saya adalah wanita yang kuat, sehat dan mampu bertanggungjawab pada anak". Selain berpikir positif Subjek juga memiliki alternatif tingkah laku positif agar konsekuensi yang dihasilkan juga positif untuk mewujudkan pemikiran yang positif.

Teknik restrukturisasi kognitif yang diberikan terapis pada Subjek dirasa tepat dan cocok dalam menangani gejala kecemasan yang dialami Subjek karena dinilai terapis sesuai dengan kebutuhan Subjek sendiri. Selain itu intervensi menggunakan terapi kognitif dengan teknik restrukturisasi kognitif yang diterapkan terapis ini cukup berhasil karena menunjukkan adanya perubahan pada Subjek baik dari pola pikirnya maupun dari perilaku yang dimunculkan Subjek.

\section{Simpulan}

Hasil dari intervensi yang sudah diberikan kepada Subjek, dapat disimpulkan bahwa intervensi ini memberikan 
perubahan kognitif dan perilaku pada Subjek menunjukkan perubahan. Dalam intervensi ini juga dapat disimpulkan bahwa penerapan terapi kognitif melalui teknik restrukturisasi kognitif dapat mengurangi atau mengatasi pemikiranpemikiran irasional atau negatif yang dimiliki oleh Subjek dengan problem kecemasan menjadi pemikiran yang lebih positif. Subjek memiliki pemikiran yang lebih positif mengenai keadaan dirinya. Subjek berpikiran bahwa lingkungan sosialnya juga banyak yang support dengan kondisi Subjek saat ini. Subjek bisa tidur lebih nyenyak tanpa rasa cemas dan gelisah, menjalani hari-harinya dengan memperbanyak aktivitasnya.

\section{Referensi}

Aprilia, N.I., \& Puspitasari, N. (2007). Faktor yang mempeengaruhi tingkat kecemasan pada wanita perimenopause. The Indonesian Journal of Public Health, 4 (1). Surabaya.

American Psychological Association. (2010). Understanding Anxiety Disorders and Effective Treatment. Washington: APA.

American Psychiatric Association. (2013). Diagnostic and statistical manual of mental disorders (5th ed.). Washington, DC: American Psychiatric Publishing.

Beck, A.T. \& Weishaar, M.E. (2005). Cognitive therapy; Curerent psychoterapies (7th edn). Belmont, CA: Thomson Brooks/ Cole (236-238).

Cormier, S. \& Nurius, P.S. (2009). Interviewing and change strategies for helpers. USA: Brooks/Cole Cengange Learning.
Davidson, G. C, Neale, J. M \& Kring, A. M. (2002). Abnormal Psychology. 9th ediiton. California.

Dobson, D \& Dobson, K.S. (2009). Evidence- Based Practice of Cognitive Behavioral Therapy. New York: The Guilford Press.

Hing, L. S. (2013). Stigmatization, Neoliberalism, and Resilience. In P. Hall \& M. Lamont (Eds.), Social Resilience in the Neoliberal Era (pp. 158-182). Cambridge: Cambridge University Press. doi:10.1017/CBO9781139542425.010

Jones, R.N. (2011). Teori dan praktik konseling dan terapi, edisi keempat. Pustaka Pelajar: Yogyakarta.

Kasdu, D. (2007). Kiat sehat menghadapi menopause. Jakarta: Pustaka Pembangunan Swadaya Nusantara.

Knapp, P. \& Beck, A. T. Cognitive therapy: foundations, conceptual models, applications and research. Braz J Psychiatry. 2008 Oct;30 Suppl 2:s54-64. doi: 10.1590/s151644462008000600002.

Nevid, J., Rathus S., \& Beverly G. (2005). Psikologi Abnormal. Jakarta: Penerbit Erlangga. Solihat, I. S. (2012). Efektivitas Teknik Restukturisasi Kognitif Untuk Mereduksi Kecemasan Sosial Remaja. FIP UPI Bandung.

Suryaningrum, C. (2007). Cognitive behavior therapy (terapi kognitif perilaku). Fakultas Psikologi. Universitas Muhammadiyah Malang.

Videbeck, S.L. (2008). Buku ajar keperawatan jiwa. Jakarta: EGC.

Wulandari, L. H. (2004). Efektivitas Modifikasi Perilaku Kognitif untuk Mengurangi Kecemasan Komunikasi Antar Pribadi. Tersedia online di e-USU Repository. 